\title{
Kamu Hizmet Aracı Olarak Web Sitelerinin Kullanılabilirliği: EBA Örneği
}

\author{
DOI: $10.26466 /$ opus.860386
}

\author{
Hicran Özlem Ilgın* - Şaziye Ceren Ulupınar** \\ * Dr. Öğr. Üyesi, Çanakkale Onsekiz Mart Üni., Ezine M.Y.O. Çanakkale/Türkiye \\ E-Posta: hicranilgin@comu.edu.tr \\ ORCID: $\underline{0000-0002-0549-0710}$ \\ ** Öğr. Gör., Çanakkale Onsekiz Mart Üni., Ezine M.Y.O. Çanakkale /Türkiye \\ E-Posta: cerenuzunay@comu.edu.tr \\ ORCID: $\underline{0000-0002-2895-5437}$
}

\section{Öz}

Teknolojinin gelişimi ile internetin dünyayı saran hızı ve mekansızlı̆̆ı içinde kamusal hizmetler de payını almış ve dönüşen ortamlar içinde e-hizmetler kamu ve devlet arasında etkileşimi artıran bir nitelik kazanmıştır. Özellikle pandemi döneminde dijital dönüşümün hızı artmış ve dünyada olduğu gibi Türkiye'de de eğitim uzaktan eğitim formatına dönüşerek 2012'den bu yana kullanılan EBA web sitesiyle öğrenci, öğretmen ve velilerin kullanımında hızlı bir artış ile kullanılır olmuştur. Bu çalışmada bir kamu hizmeti olarak eğitimin dijital ortamda gerçekleştirilebilmesi amacıyla oluşturulan EBA web sitesinin veliler açısından kullanılabilirliğinin değerlendirilmesi amacıyla "web sitesi kullanılabilirliği anketi" uygulanmıştır. Bu kapsamda anketin pandemi döneminde gerçekleştirilmiş olması nedeniyle çevrimiçi gerçekleştirilen anketler, çocuğu EBA web sitesi üzerinden eğitim alan velilere gönüllülïk esasıyla uygulanmıştır. Anket 06-07 Ocak 2021 tarihleri arasında gerçekleştirilmiş ve sosyal medya yoluyla katılımcılara ulaştırılmıştır. Çevrimiçi ankete 602 veli katılmıştır. Araştırma sonucunda katılımcıların değerlendirilen dört kategoride web sitesinin içeriği, düzeni ve okunabilirliği $i$, web sitesi içinde gezinebilme ve bağlantıları değerlendirme, web sitesinin ara yüzünü değerlendirme ve sayfanın performansı ve etkililiğini değerlendirme kategorilerinde EBA web sitesinin "kullanılabilir olduğunu" orta düzey üstünde bir oran ile belirttikleri kayıt altına alınmıştır. Çalışma sonucuna göre bir kamu hizmeti olarak değerlendirilen EBA eğitim platformu, veliler tarafindan kullanılabilir olarak değerlendirildiği söylenebilir.

Anahtar Kelimeler: Kamu Hizmeti, Halkla İlişkiler, Dijital İletişim, Web Sitesi, EBA 


\title{
Usability of Websites as a Public Service Tool: EBA Example
}

\begin{abstract}
With the development of technology, public services have also taken their share in the speed and spacelessness of the internet that surrounds the world and e-services have gained a quality that increases the interaction between the public and the state in the transforming environments. Especially pandemic period digital conversion speed is increased and, as in the world and in Turkey used since 2012 by transforming into education distance learning formats EBA website with students in the use of teachers and parents has been used with a rapid increase. In this study, a "web site usability questionnaire" was applied in order to evaluate the usability of the EBA web site, which was created in order to provide education in a digital environment as a public service. In this context, since the survey was conducted during the pandemic period, online surveys were applied on a voluntary basis to parents whose children receive education on the EBA website. The survey was conducted between 06-07 January 2021 and delivered to the participants via social media. 602 parents took part in the online survey. As a result of the research, it was recorded that the participants stated that the EBA website was "usable" with a rate above medium level in the categories of content, layout and readability of the website, navigating within the website and evaluating the links, evaluating the interface of the website and evaluating the performance and effectiveness of the page. has been taken. According to the results of the study, it can be said that the EBA education platform, which is considered a public service, is considered to be usable by parents.
\end{abstract}

Keywords: Public Service, Public Relations, Digital Communication, Website, EBA 


\section{Giriş}

Yaşanan teknolojik gelişmeler bilginin üretilmesi, bilimin üretilmesi, bilgiden bilginin üretilmesi ve aktarılması noktasında hayatımızın hemen hemen her alanında değişiklikleri de beraberinde getirdiği görülmektedir. Günümüzde yaşamın içinde yapılacak işlerin birçoğunu online olarak yapabilmek bireyler için zaman kaybının önüne geçebileceği gibi görece avantajlar sağlamaktadır. Bugün devletlerin hizmetlerini sunma aracı haline de dönüşen internet, yönetim anlayışı perspektifinden baktığımızda ise şeffaf, demokratik, katılımcı ve hesap verebilirlik kavramların da olumlu bir biçimde yapılandıran bir kavramdır. Bu bağlamda internetin zaman ve mekân sınırı tanımayan interaktif ortamı iletişim açısından efektif olarak kullanıldığında devlet hizmetlerinin üretilmesi noktasında avantaja dönüşmektedir. Devletin kamu hizmetlerinden eğitimin teknoloji ile beraberinde değişimi meydana getirmiştir. Bilgi ve iletişim teknolojilerinin günümüzde eğitime entegre edilmesi yönünde çalışmalar yapılmaktadır.

Türkiye'de Yenilik ve Eğitim Teknolojileri Genel Müdürlüğü tarafından, Eğitim Bilişim Ağı (EBA) öğretmen, öğrencilerin ve velilerin kullanımına ücretsiz bir şekilde çevrimiçi sosyal eğitim platformu oluşturulmuştur. Bu sistem ile öğretmen, öğrenci ve veliler eğitsel içeriklere yazı, ses, resim özelliklerinin yanı sıra videolu anlatım gibi kaynaklara da erişebilme imkânına sahiptirler. Eğitim ve öğretim kaynaklarının elektronik ortamda sunulması, öğrencilerin bilgiye erişimine katkı sağlayarak, öğrenme süreçlerine destek sağlamaktadır. Bunun yanı sıra EBA öğrenciye ilişkin performans bilgilerine veli tarafından ulaşabilme imkânı sunmaktadır. Bu da EBA'nın öğrenci, öğretmen ve veli etkileşimli ortamını ortaya koymakta bu noktadan hareketle velileri de hedef kitle haline getirmektedir. Özellikle pandemi döneminde yüz yüze eğitimin okullarda devam edemediği ve evden dijital olarak gerçekleştirilen bir eğitim döneminde veli, öğretmen ve öğrenci üçgeninde EBA web sitesi önemli bir eğitim ortamı olarak bir kamu hizmeti olarak karşımıza çımaktadır.

Bu noktalardan hareketle bu çalışmada pandemi döneminde önemini hissettiren elektronik öğrenme ortamı olan EBA web sitesinin bir devlet e-hizmeti olarak veliler tarafından değerlendirilmesini konu almaktadır. Çalışmanın literatür bölümünde kamu hizmet aracı olarak web siteleri ve örnekleri ile EBA ortamına ilişkin yazınlar değerlendirilecektir. Çalışmada çevrimiçi 
anket yöntemi ile uygulanan web sitesi kullanılabilirlik değerlendirilmesi bulgular bölümünde yapılacaktır.

\section{Kamu Hizmet Aracı Olarak Web Siteleri}

1990'li yıllardan sonra devrim niteliği taşıyan Tim Berners-Lee ve ekibi, Avrupa Parça Fiziği Laboratuvarı'nda (CERN) bilgi dağıtımı amaciyla yeni bir protokol önermişlerdir. 1991 yılında adı anılmaya başlanan "World Wide Web" (www) diye adlandırılan protokol kullanılmaya başlamasıyla hızla bu yapı yenilikler üretmeye başlamıştır. Gelişimin devam etmesiyle ihtiyaçların belirlenmesine göre internet farklı internet sitelerine evrilmeye başlamış ve web teknolojilerinin temelleri atılmıştır. Daha sonrasında Webs 1.0 yetersizliğinden dolayı web 2.0 doğmuştur. Web 2.0 insan etkileşimli olarak nitelendirilmektedir. Bu bağlamda İnternet kullanıcılarının belli platformlarda paylaşarak ve ortaklaşa oluşturduğu sistemi tanımlamaktadır. Web 3.0 ise internet kontrolünün insan elinden çıktığı bir web dünyası olarak tanımlanmaktadır. Cihazlar arası etkileşimle internetin web dünyası olarak söylenebilir (Kutup,2010, s.12-13). Bu sayede her biri sahip olduğu farklıllklarla internet dünyasına yeni anlam ve özellikler kazandırmaktadır. Kullanıcıların ihtiyaçlarını fark ederek o alana yönelik iyileştirme çalışmaları yapabilme imkânı ortaya çıkmaktadır. Özellikle günümüzde giderek önem kazanan dijital iletişim alanında da önemli yenilikler sunabilmektedir.

Günümüzde kar amacı güden ve kar amacı gütmeyen kurumlar çeşitli hedef kitlelerle iletişim kurarlar ve bu iletişimden olumlu sonuçlar elde etmek isterler. Çevre ile kurulan iletişim dâhilinde kurumlar için olumlu sonuçlar çıkarılması hedeflenen çalışmalarına yön verebilmektedir. Kurumların şeffaf olması hedef kitleleriyle doğrudan iletişime geçebilmelerine olanak tanımaktadır (Kazanc1, 1997, s.30). Bu nedenle web siteleri kurumlar ile ilgili bilgileri sunma noktasında şeffaflık yaratabilmektedir. Mükemmel halkla ilişkiler çalışmalarının temelinde çift yönlü iletişime dayandırılsa da günümüzde bilgilendirme yönüyle tek taraflı iletişimi barındıran halkla ilişkiler çalışmaları da varlığını sürdürmektedir (Grunig 2005, s.330). Bu bağlamda web sayfalarinda hedef kitlenin kurumu tanıması, bilgi edinmesi ve olumlu izlenimlerin oluşması bakımından önem arz etmektedir. Kurumlar web sayfa kanalını kullanarak kuruluş amacı, yöneticiler, organizasyonlar, faaliyetler vb. bilgiler ile hizmetlerini hedef kitle ile paylaşarak bilgilenmesini sağlamaktadır. 
Web sitesi detseğiyle gerçekleşen e-devlet; kamu hizmetlerinin, tarafların doğrudan bağlantı kurmaya ya da fiziksel değiş tokuş yapmaya gerek kalmadan açık veya sınırlı kullanıcıların ulaşabildiği kapalı ağlar üzerinden elektronik olarak yapılabilmesi şeklinde tanımlanabilir (Çukurçayır ve Eşki, 2001,s.104). E-devletin anlamı, devletin vatandaşlara karşı yerine getirmekte yükümlü olduğu görev ve hizmetler ile vatandaşların buna karşılık devlete karşı olan görev ve hizmetlerinin karşılıklı olarak elektronik iletişim ve işlem ortamlarında kesintisiz ve güvenli olarak yürütülmesidir. E-devlet çalışmalarıyla dilimize birçok " $\mathrm{e}$ " ile başlayan kavram eklenmiştir (TBD, 2006, s.8). Bu bağlamda e-okul uygulaması bir kamu hizmeti olarak öğrenci, öğretmen ve velilerin kullanımına sunulmuş bir e-devlet hizmetidir.

Hedef kitleye ulaşmada yeni iletişim türünün ortaya çıkardığ 1 kavramlardan biri de e-katılımcılıktır. Birleşmiş Milletler E-devlet 2008 Araştırma Raporuna göre devlet uygulamalarında bilgi teknolojilerinin en önemli bileşenlerden birisi olan e-katılım için etkili bir platformun sunulması gerekliği belirtilmiştir. Devlette daha fazla şeffaflık olma yolunda önemli adım olan ekatılımcılık, bireylere etki kanallarını kullanma yolunu da açmaktadır. Bu bakımdan uygulamaların ve web sitesi işlevselliğinin şu özelliklere sahip olması gereklidir (Erkul, 2009, s.3):

- Yayıncıdan bağımsız olarak kullanıcıların olması,

- Kullanıcı taraflı içeriklerin olması,

- Kullanıcıların arasında etkileşimin var olması,

- Zaman ve mekân sinırlamasının olmamasi.

Kamu kurumlarının web siteleri tasarım bakımından hizmet kalitesini arttıracak ve bireyleri tatmin edecek seviyede olması beklenmektedir. Genellikle web site tasarımlarında site özellikleri ve görsellik üzerine yoğunlaşılmaktadır. Kullanıcı merkezli bir web site tasarımı ise daha kullanışlı olabilmektedir. Kullanıcı merkezli tasarımın temelinde, kullanıc beklentilerine göre şekil alan, deneme ve tasarım aşamalarında ise kullanıcıları odak noktasına yerleştiren bir tasarım felsefesi olarak da açıklanabilir. Tablo 1' de de ifade edildiği gibi kullanıcı merkezli yaklaşım üç farklı açıdan değerlendirilmektedir. Bunlar; işlevsellik, kullanılabilirlik ve erişilebilirlik özellikleridir (Bertot ve Jaeger, 2008, s.150-153): 
Tablo 1. Kullanıcı Odaklı Tasarım Yaklaşımı

\begin{tabular}{ll}
\hline Yöntem & Amaç \\
\hline İşlevsel Özellikleri & Web sitesinde hedeflenen işlemlerin ne kadar etkin \\
& bir şekilde gerçekleştiği değerlendirilmektedir. \\
& Web sitesinin tasarlanan ve beklenen işlevleri ye- \\
& rine getirilip getirilmediğine bakılmaktadır. \\
\hline Kullanılabilirlik Özellikleri & Kullanılabilirlik özelliği web sitesini kullanım bakı- \\
& mindan verimlilik, kolaylık gibi genel kaliteyi de- \\
& ğerlendirmek için kullanılmaktadır. \\
\hline Erişilebilirlik Özellikleri & Erişilebilirlik testleri ise, web sitesinin kullanıcılara \\
& eşit imkan erişim imkanı sağlayıp sağlamadığını \\
& denemek amacıyla kullanılmaktadır. \\
\hline
\end{tabular}

Literatür incelendiğinde, eğitimde teknoloji kullanımının önemini ortaya koyan çalışmalara rastlanmaktadır. Bu bağlamda web sitelerinin kullanılabilirliğini ölçen çalışmalar mevcuttur. West (2004, s.15-27) çalışmasında, kamuda araştırma, hizmet sunumunu ve demokratik duyarlıllğı geliştirmek ve iyileştirmek amacıyla e-devlet içeriğini incelemiştir. Durmuş ve Çağıltay (2012, s.293-322) ise 33 kamu kurumunun web sitesi bu bağlamda içerik analiziyle incelemiştir. Kocabulut ve Albayrak (2017, s.293-303), ulusal bir havayoluna ait işletmenin web sitesinin kullanılabilirlik memnuniyetini karşılaştırma yoluyla araştırmasında yer vermiştir. Yllmaz vd. (2020) ise araştırmalarında pandemi sürecinde öğretmen ve öğrencilerin yararlandığ 1 MEB'in uzaktan eğitim faaliyetlerini veli görüşlerine göre ölçmeye çalışmışlardır. Bu noktada bu çalışma veliler açısından web sitesinin kullanılabilirliğinin değerlendirilmesi noktasında önem arz etmektedir.

Teknolojik gelişmelere uyum sağlamak ve enformasyon çağının bir parçası olmak amacıyla Türkiye'de 2000'li yıllardan itibaren bu alanda oldukça önemli çalışmalar yapılmaktadır. Bu çalışmalar kapsamında kamu hizmetinin birçok alanda elektronik ortam sunumlarının başlaması öngörülmüştür. Bu amaç kapsamında önemli adımlar atılmıştır. Bu kapsamda ki çalışmalar ise (Durmuş ve Çağlltay, 2012, s.296-298):

- 2005 - DPT(Devlet Planlama Teşkilatı) Birlikte Çalışabilirlik Esasları

- 2006 - Kamu Kurumları İnternet Sitesi Kılavuzu

- 2006 - Sayıştay Başkanlığı Performans Denetim Raporu

- 2009 - TÜRKSAT Kamu Kurumları İnternet Siteleri Standartları ve Önerileri Rehberi

- 2011 - TÜİK (Türkiye İstatistik Kurumu)Bilgi Toplumu İstatistikleri 
Elektronik ortamda yapılan önemli adımlarda 2000'li yılların başından itibaren bu alandaki yatırımlar olduğu görülmektedir. Şekil 1. de Kamu bilgi teknolojileri yatırımları gösterilmektedir.

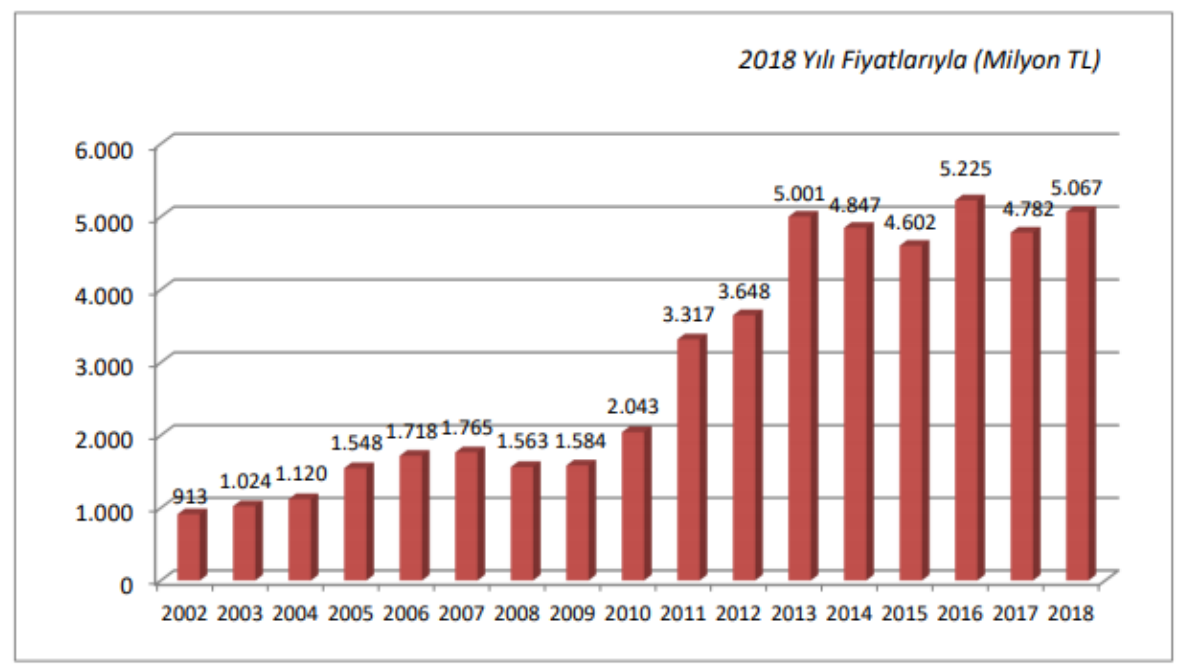

Şekil 1. Kamu Bilgi Teknolojileri Yatırmmlarn (2002-2018)(http://www.bilgitoplumu.gov.tr/timeline)

2002 yılında kamu bilgi teknolojilerinin yatırıma 913 milyon TL ile başladığı görülmektedir. 2007 yılına kadar BİT(Bilgi İletişim Teknolojileri) yatırımlarının arttığı görülmektedir. 2008 yılında 202 milyon TL lik bir yatırım düşüşünün ardından 2011 yılından sonra yaşanan büyük artış görülmektedir. 2018 yılı yatırım fiyatlarıyla aradan geçen 16 yıllık süre dâhilinde 5 kattan daha fazla bir artış kaydedilmiştir. BİT yatırımlarına 2018 yılında ise projeler için 5 milyar 67 milyon TL ödenek tahsis edildiği Şekil 1. de görülmektedir.

BİT 2002-2018 yılları arası yatırımlarından sonra yapılan bu yatırımların hangi sektörlere yapıldığı ise Şekil 2. de gösterilmektedir. 


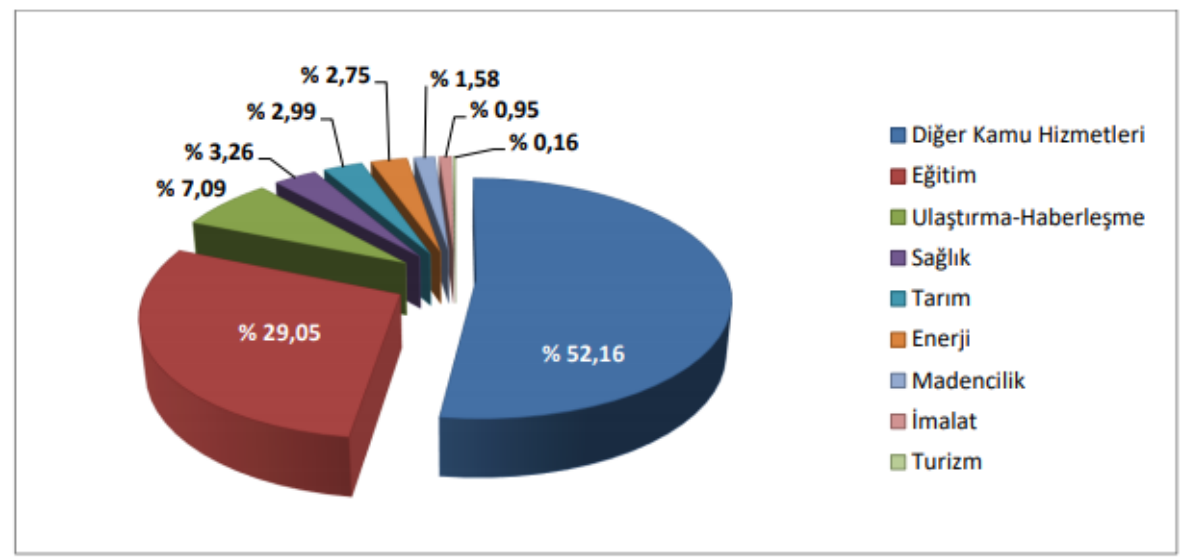

Şekil 2: Kamu BITT Yatırımları Sektörel Dă̆ılımı, 2018

(http://www.bilgitoplumu.gov.tr/timeline/)

Kamu BİT yatırımları için öngörülen 2018 yılı sektörler arası dağılımı Şekil 2. de gösterilmektedir. Şekle bakıldığında birinci sırada \%52.16'lık payla diğer kamu hizmetlerinin olduğu görülmektedir. Diğer kamu hizmetleri kategorisine giren; İçişleri Bakanlığı, Sosyal Güvenlik Kurumu, Adalet Bakanlığı ve Emniyet Genel Müdürlüğü gibi kurumlardır. E-devlet projeleri kapsamında bu kurumlara yatırım yapıldığı bilinmektedir. Yatırımların 2. sırasında yer alan sektör ise eğitim alanıdır. Milli eğitim bakanlığı ve üniversitelere ait olan bu yatırımlar \%29,05'lik bir payla yer almaktadır. 3. sırada ise \%7.09'luk bir payla ulaştırma-haberleştirme sektörü eğitim sektörünü takip etmektedir. Diğer sektörel yatırım dağılımları sırasıyla; sağlık, tarım, enerji, madencilik, imalat ve turizmdir.

\section{Bir E-Hizmet Olarak Uzaktan Eğitim ve Eğitim Bilişim Sistemleri(EBA)}

Teknolojinin gündelik hayatın birçok aşamasında kullanılması, eğitim alanında kullanılan öğretim modellerinin de bu alanda kullanmayı beraberinde getirmiştir. Bu öğretim modeli öğrenciyi aktif ve daha hızlı öğretim ortamlarına dahil edebilen, kişisel olarak çalışmasına olanak sağlayan, çoklu duyu organlarından yaralanarak öğrenmeye katkıda bulunan ve tekrar etme imkanı sunan son zamanların vazgeçilmezi durumuna gelmiştir (Çakmak veTaşkıran, 2017, s.284). 
Bu alanda Türkiye'de resmi anlamda ilk adımlar 2012 yılından itibaren atılmıştır. Bu adımların ilki "Fırsatları Artırma ve Teknolojiyi İyileştirme Hareketi" (FATİH) hayata geçirilmiştir. Hayata geçirilen bu projede öğrenim sürecini etkileyen "e-içeriğin sağlanması ve yönetilmesi" olmuştur. Eğitim ve öğretimi kapsayan bu süreç içim Milli Eğitim Bakanlı̆̆ı(MEB) Yenilik ve Eğitim Teknolojileri Genel Müdürlüğü (YEĞITTEK) tarafından güvenilir e-içeriklerin hazırlanması bakımından Eğitim Bilişim Ağı (EBA) 2012 yılında hizmete sunmuştur. EBA her sınıf seviyesine uygun bir şekilde eğitim-öğretim içeriklerinin güvenilir olduğu bir platform olarak sunulmuştur. EBA'nın kuruluş amacını MEB “ evde, okulda ya da ihtiyaç duyulan her yerde bilgi teknolojilerini kullanarak materyali en etkin şekilde kullanarak teknolojinin eğitime uyumunu sağlamaktadır" şeklinde belirtmiştir (Öner, 2017: 228). 20152016 eğitim-öğretim yılından itibaren belirli aralıklarla MEB öğretmenlere EBA hakkında hizmet içi eğitim olanağı sunmaktadır. Bu kapsamda fırsat eşitliğine ve farklı öğrenme stiline sahip öğrencilere imkân tanıyan EBA 'ya öğretmenlerin öğrencilerini dâhil etmeleri beklenmektedir. EBA herkes tarafından ulaşılabilen ve çeşitli içeriklere sahip modüllerden oluşmaktadır.

EBA platformu (Bal ve Boz, 2017, s.6);

- İnteraktif, zengin, farklı ve eğitici içerikler sunmak, eğitimde bilişim anlayışını yaygınlaştırarak kullanılmasını sağlamak,

- İçeriklerle ilgili kullanıcı ihtiyaçlarına cevap vermek, sosyal ağ platformuyla bilgi alışverişlerinin oluşmasını sağlamak,

- Gittikçe büyüyen arşiviyle ve zengin içeriğiyle derslere katkı, öğrenirken aynı zamanda bilgiden bilgi üretmek,

- Farklı öğrenme biçimlerine (sayısal, sözel, sosyal, görsel, işitsel, bireysel, öğrenme) sahip olan öğrencileri kapsamak,

- Öğretmenleri ortak bir paydada buluşturarak eğitime yön vermelerini ve katkı vermelerini sağlamak,

- Her geçen gün gelişim gösteren teknolojiyi eğitim hayatında amaç olarak değil araç olarak kullanmayı sağlamak amacıyla oluşturulmuştur.

2019 yılında Coronavirüs pandemisinin ortaya çıkmasıyla uzaktan eğitim platformları da önemli bir öğrenme kaynağı durumuna gelmiştir. Dünya genelinde eğitim üzerinde pandeminin etkisi de farklı ihtiyaç ve yaklaşımları da ön plana çıarmıştır. Pandemi, öğrenme sürecinin sekteye uğratılmadan sürdürülmesinin gerektiğini, uzaktan eğitime daha fazla ihtiyacın olduğu ve 
bu alana yatırımın yapılması gerektiğini, alternatif öğrenme yaklaşımlarına önemin gerektiğinden fazla verilmesini göstermiştir. Uzaktan eğitim uygulamalarının normal öğretim zamanlarının dışında da doğal afetler, savaşlar, salgın hastalıklar, vb. kriz durumlarının olabileceği ortamlar düşünülerek bu uygulamalar dikkate alınmalıdır (Can, 2020, s.12). Bu bağlamda EBA gibi uzaktan eğitim platformları kriz zamanlarında karşılaşılan sorunların çözümünde önemli bir eğitim-öğretim platformu haline gelmiştir. Böylece yüz yüze verilen eğitimi desteklemek amacıyla EBA platformu, pandemi süreciyle beraberinde eğitim faaliyetlerinin sürdürüldüğü bir ortam haline gelmiştir. Tüm öğrencilere erişim imkânlarının aynı olamayacağı düşünülerek TRT, EBA TV ve videolar ile EBA platformu ilkokul, ortaokul, lise olmak üzere kategorize edilerek yayınlanmıştır (http://www.eba.gov.tr/nasiltv.html).

Ünlü arama motoru olan Google'ın 2020 yılı arama trendlerine göre birinci sırada EBA en çok aranan kelime olmuştur (https://trends.google.com.tr/trends/yis/2020/TR/). Coronavirüs pandemi sürecinde ulusal ölçekte uzaktan eğitim-öğretim ağı olan EBA, internet trafiği kriterlerine göre ve kullanım miktarlarına göre eğitim alanındaki tüm web siteleri arasında dünyada birinci sıraya yükselmiştir. Son olarak da 1 Ekim 2020 tarihinden itibaren önceki aylara göre 27 basamak daha yükselerek küresel platformda eğitim alanında 1. sıraya çıkmıştır (http://yegitek.meb.gov.tr/www/eba-egitim-platformu-dunyada-1-siraya-yerlesti/icerik/3092).

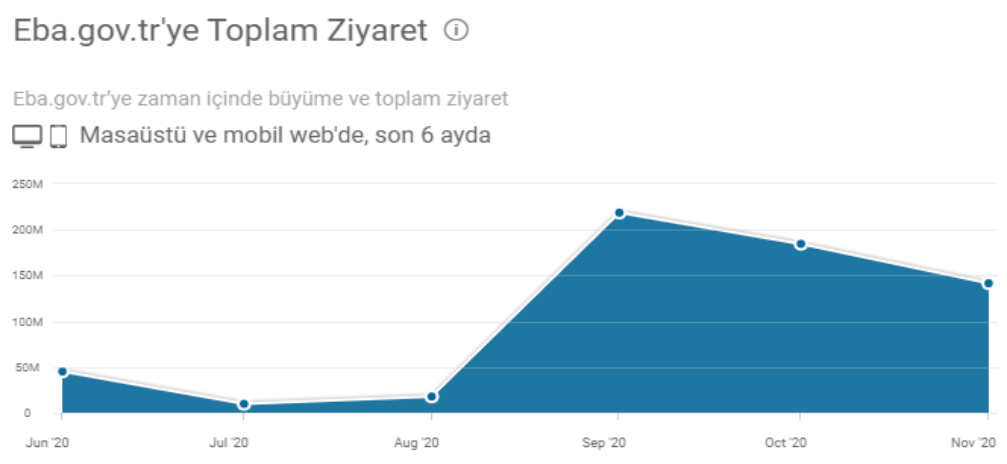

Şekil 3. EBA web sitesi istatistikleri (Haziran-Kasım 2020) (https://www.similarweb.com/website/EBA.gov.tr/\#overview) 
Şekil 3. de EBA web istatistikleri (Haziran-Ağustos 2020) verilmiştir. 6 aylık süreçte kaç milyon masaüstü ve mobil web ortamında ziyaretler gösterilmektedir. Bu süreçte 6 aylık toplam ziyaret sayısı 617 milyon 431 bin 463 olarak kayda geçmiştir. Eğitim-öğretim yılının son ayları olan Haziran ayında EBA'ya ortalama ziyaret sayısı 50 milyon olarak görülmektedir. Yaz dönemiyle birlikte ziyaretçi sayılarında düşmeler görülmektedir. Temmuz ve Ağustos aylarında ise bu rakam 50 milyonun altına düşmektedir. 2020-2021 eğitim-öğretim yılının başlamasıyla birlikte Eylül ayında ziyaretçi sayısı 200 milyonu geçmiştir. Ekim ayında ise 184 milyon ziyaretçisiyle Eylül ayına göre düşüş göstermektedir. Kasım ayında ise 141 milyon ziyaretçi sayısıyla son iki aya göre düşüş görülmektedir.

Alan yazın incelendiğinde yine bu eksende EBA, web sitesi kullanılabilirlik ve uzaktan eğitim hakkında çalışmalar görülmektedir. EBA platformunda öğretmen ve öğrencilerin görüşlerine dair kavram haritalarının incelendiği (Karaçorlu ve Atıcı,2019, s.84-102), öğretmenlerin EBA algılarıyla ilgili bir modelleme yoluyla incelendiği (Dündar ve Karaağaçl1,2019, s.247-259), EBA katılım portalının nicel ve nitel olarak incelendiği (Demir, Özdinç ve Ünal, 2018, s.407-422), uzaktan eğitim programların betimsel olarak incelendiği (Kaçan ve Gelen,2020, s.21), uzaktan eğitimi alan yazını taraması ile incelendiği (Akyürek,2020,s.1-9) gibi birçok çalışma bulunmaktadır.

Uzaktan eğitim ve yapılan diğer yenilikler artık belli plan ve program, zaman ve yer kısıtlamasının olduğu geleneksel eğitimi değil; esnekliğin, bağımsızlığın interaktif eğitimin var olduğu hayat boyu eğitim anlayışının yolu açılmıştır. Uzaktan eğitim süreci yüz yüze olmayı gerektirmediği için teknolojik araçlarla sağlanabilmektedir. Bu araçlar yoluyla sağlanan eğitim, öğrenci etkileşimli ve yararlı eğitim ortamını oluşturabilmektedir. Bu anlayışın yola ç1karak uzaktan eğitim konusu dünyadaki yaşanan gelişmelere paralel olarak Türkiye'de de gelişme göstermiştir. İnternet alt yapılı uygulamalardan biri olan EBA uzaktan eğitim yolunda öğretmen ve öğrenciler için interaktif bir platform olmuştur.

\section{Araştırmanın Yöntemi}

Bu araştırmanın konusu Covid 19 pandemisi döneminde çocuğu EBA sisteminin web yüzünü kullanan ebeveynlerin web sitesinin kullanılabilirliğine 
ilişkin düşünceleridir. Araştırmanın amacı uzaktan eğitim döneminde değerlendirilen EBA uzaktan eğitim pltarformunun veliler nezdinde ne ölçüde kullanılabilir olduğunu ortaya koymaktır. EBA'ya ilişkin yapılan araştırmaların öğretmen ve öğrenci olmasından hareketle veliler ile yapılan bir araştırmanın alan yazında önem taşıyacağı düşünülmektedir.

Araştırmanın yönteminde Chiew ve Salim'in (2003, s.47-57) geliştirdiği ve "Webuse: Website Usability Evaluation Tool" çalışmasında yer alan 24 soruluk ölçek, çevrimiçi anket yöntemi ile kullanılmıştır. Ankette kullanılacak ölçek Çanakkale Onsekiz Mart Üniversitesi Lisansüstü Eğitim Enstitüsü Bilimsel Araştırmalar Etik Kurulu'nun almış olduğu 04/01/2021 tarih ve 01/24 sayılı karar ile Bilimsel Araştırmalar Etik Kurul ilkelerine uygun olduğuna oy birliği ile karar verilerek değerlendirilmeye alınmıştır. Araştırmada sorulan sorular; web sitesinin içeriği, düzeni ve okunabilirliği 6 soru, web sitesi içinde gezinebilme ve bağlantıları değerlendirme 6 soru, web sitesinin ara yüzünü değerlendirme 6 soru ve sayfanın performansı ve etkililiğini değerlendirme olmak üzere 6 soru ve 4 ana kategori altında değerlendirilmiştir. Ankette aynı zamanda demografik değerlendirmeleri yapabilmek amaciyla katılımcların cinsiyeti, yaşı, mesleği, yaşadığı şehir, eğitim durumu, çocuğun eğitim düzeyi ve EBA erişimi sağladıkları cihaz da sorulmuştur. Anket pandemi döneminde gerçekleştirilmesi nedeniyle çevrim içi olarak gerçekleştirilmiştir. Anket ön değerlendirme amacıyla başlatılmadan önce dijital platformda 20 katılımcıya uygulanmış, güvenilirlik sonuçları değerlendirilmiş ve 06-07 Ocak 2021 tarihleri arasında Google Docs üzerinden hazırlanan anket sosyal medya platformlarında açık katılıma sunulmuştur. Anket örneklemi için belirlenen 384 rakamına ulaşılması anket uygulama süresi için ana koşul olarak belirlenmiş bu süre içinde online olarak katılımlar gerçekleştirilmiştir. Belirlenen bu sürenin içinde planlanan rakamın üzerine katılımcıya ulaşılmıştır.

Araştırma örneklemi çocuğu EBA internet sitesi üzerinden eğitimini gerçekleştiren velilerden oluşmaktadır. Anketin çevrimiçi gerçekleştirilmesi nedeniyle her hangi bir coğrafik sınırlama bulunmamaktadır. Araştırmanın çevrimiçi olması ve sosyal medya kanalıyla Türkiye genelinde gerçekleştirilmesi nedeniyle hedeflenen örneklem rakamı 384'tür. Araştırma için ayrılan süre kapsamında bu rakamın üstüne ç1kılarak toplam olarak 602 kişiye/veliye ulaşılmıştır. Buna göre katılımcıların 495'i, \%82.2'si kadın, 107'si, \%17.8'i erkek olarak kayıt altına alınmıştır. Katılımcıların $27^{\prime}$ si \%4.5'u 25 yaş ve altı, 197'si \%32.7'si 26-35 yaş arası, 309'u \%51,3'ü 36-45 yaş arası, 65'i \%10,8'i 46- 
55 yaş arası ve 4'ü \%0.57'si 55 yaş üstüdür. Katılımclların 133'ü \%22.1'i ilkokul, 83'ü \%13.8'i ortaokul, 134'ü \%22.3'ü lise, 221'i \%36.7'si üniversite ve 31'i $\% 5.1$ 'i lisansüstü eğitim düzeyindedir.

\section{Araştırma Bulgulanı}

Araştırmaya katılan velilerin çocuklarının eğitim durumu 54 frekans $\% 9$ oran ile okul öncesi, 273 frekans \%45.6 ile ilkokul, 167 frekans \%28 oran ile ortaokul, 108 frekans \%18 oran ile lise olarak kayıt altına alınmıştır.

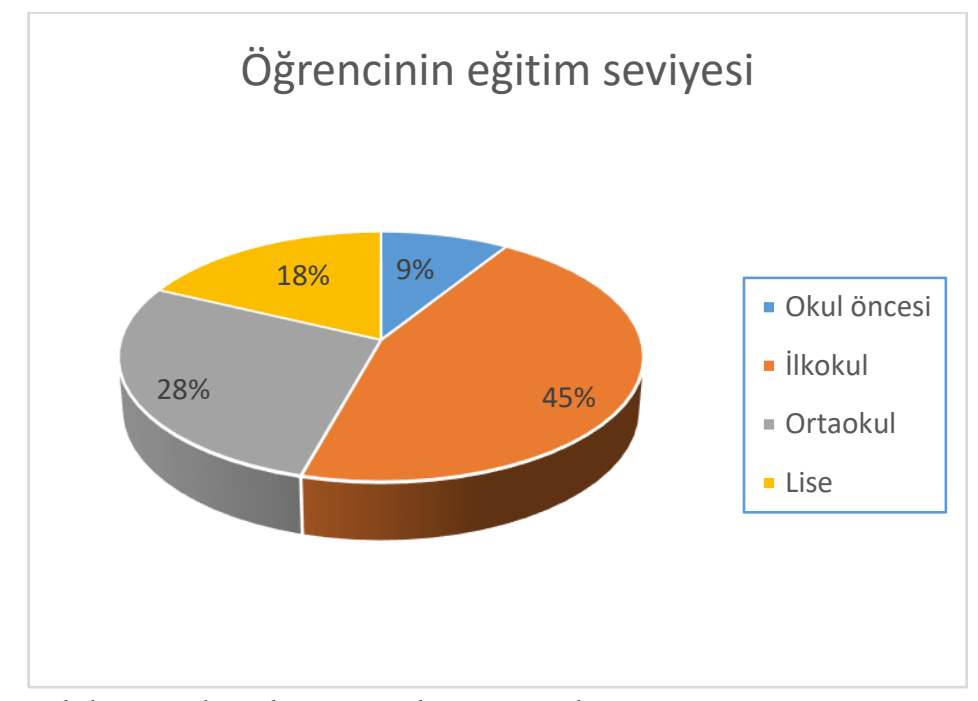

Şekil 4. Katılımcılarn EBA'dan eğitim alan çocuğunun eğitim seviyesi

Öğrencilerin öncelikli olarak hangi cihaz ile EBA platformuna bağlandıklarını arayan soruya katılımcların 44 frekans \%7 oran ile masaüstü bilgisayar, 88 frekans \%15 oran ile tablet, 190 frekans \%32 oran ile dizüstü bilgisayar, 280 frekans \%47 oran ile cep telefonu yanıtı alınmıştır. 


\section{EBA'ya bağlandıkları cihaz bilgisi}

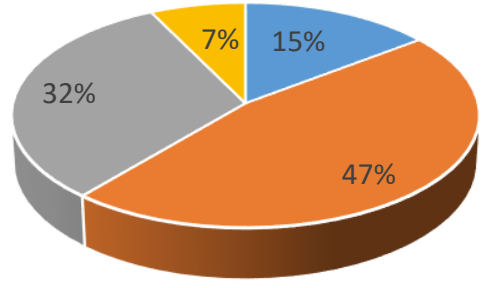

- Tablet

- Telefon

- Dizüstü bilgisayar

- Masaüstü bilgisayar

Şekil 5. EBA'ya bağlandıkları cihaz bilgisi

Araştırma bulguları araştırma ölçeğinden hareketle dört bölümde değerlendirilecektir. Buna göre web sitesinin içeriği, düzeni ve okunabilirliği, web sitesi içinde gezinebilme ve bağlantıları değerlendirme, web sitesinin ara yüzünü değerlendirme ve sayfanın performansı ve etkililiğini değerlendirme olmak üzere 4 ana kategori bulgulara verilecektir.

Web sitesinin içeriği, düzeni ve okunabilirliği kategorisinde katılımcılara 6 soru sorulmuştur. Buna göre EBA web sitesinin eğitim için gerekli konuları içerdiği yargısına katılımcıların 51 \%8.5'u kesinlikle katılıyorum, 272'si \%45.2 oranla katılıyorum, 151'i \%25.1 ile kararsızım, 99'u \%16.4'ü katılmıorum, 29 'u \%4.8'i kesinlikle katılmıyorum şeklinde cevap vermiştir. EBA web sitesinde istediklerimi buluyorum yargisına 46's1 \%7.6 oran ile kesinlikle katıllyorum, 270'i \%44.9'u katılıyorum, 154'ü \%25.6 ile kararsızım, 103'ü \%17.1'i katılmıyorum, 29'u \%4.8 ile kesinlikle katılmıyorum yanıtını vermiştir. EBA web sitesinin EBA web sitesi içeriğinin iyi organize dildiğine ilişkin yargıya katılımcıların 43'ü \%7.1 kesinlikle katılıyorum, $296 \% 23.4$ 'ü oranla katilıyorum, 141 ile \%23.4'ü kararsızım, 88'i \%14.6'sı katılmıyorum, 34'ü \%5.6'sı kesinlikle katılmıyorum şeklinde cevap vermiştir. EBA web sitesinde içerik okumak kolaydır yargısına katılımciların 43\%7.1 kesinlikle katılıyorum, 345' i 
\%57.3 oranla katılıyorum, 121'i \%20.1 ile kararsızım, 69'u \%11.5'i katılmıyorum, 24 'ü \%4'ü kesinlikle katılmıyorum şeklinde cevap vermiştir. EBA web sitesinde kullanılan dile aşina olmama yargısına katılımcıların 68'i \%11.3 ile kesinlikle katılıyorum, 379'u \%63 ile katilıyorum, 83'ü \%13.8'i kararsızım, 53 'ü \%8.8 oran ile katılmiyorum, 19'u \%3.2 ile kesinlikle katılmıyorum yanıtını vermiştir. EBA web sitesinde sayfayı okurken sola sağa kaydırmanın gerekliliği yargısına katılımcıların 53 ile \%8.8 oran ile kesinlikle katılıyorum, 299'u \%49.7 ile katıllyorum, 117'si 19.4 ile kararsızım, 105'i \%17.4 ile katılmıyorum, 28'i \%4.7'si kesinlikle katılmıyorum yanıtı kayıt altına alınmıştır. Aşağıdaki pasta grafikte web sitesinin içeriği, düzeni ve okunabilirliği kategorisinin ağırlıklı ortalama oranları verilmiştir. EBA web sitesinin içeriği, düzeni ve okunabilirliği kategorisinde "kullanılabilir" olduğuna ilişkin katılımcıların \%8.4 oranında kesinlikle katılıyorum, \%:51.5 oranında katılıyorum, \%21.2 oranında kararsızım, \%14.3 oranında katılmıyorum, \%4.5 oranında kesinlikle katılmıyorum yanıtını verdiği sonucuna ulaşılmıştır. Bu verilere göre EBA web sitesinin veliler tarafından sitenin içeriği, düzeni ve okunabilirliği kategorisinde orta düzeyin üstünde kullanılabilir olduğunuza ilişkin fikir beyan ettiği söylenebilir.

\section{Web sitesinin içeriği, düzeni ve okunabilirliği kategorisi}

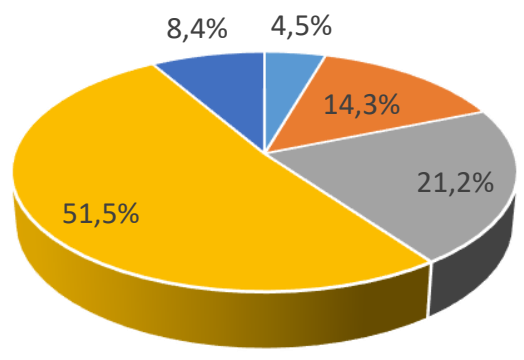

- kesinlikle katılmıyorum

- katılmıyorum

- kararsızım

- katılıyorum

- kesinlikle katılıyorum

Şekil 6. Web Sitesinin İçeriği, Düzeni Ve Okunabilirliği Ağırlıklı Ortalama Grafiği 
Katılımcllara ikinci kategoride web sitesi içinde gezinebilme ve bağlantıları değerlendirme üzerine 6 soru sorulmuştur. Velilerin EBA web sitesini kullanırken sitenin neresinde olduğunu bildiklerine ilişkin yargıya katılımc1ların 50'si \%8.3'ü kesinlikle katıllyorum, 350'si \%58.1 ile katıllyorum, 112'si \%18.6 ile kararsızım, 72'si \%12 ile katılmıyorum, 18'i \%3 ile kesinlikle katılmıyorum yanıtını vermiştir. EBA web sitesinin istenen bilgileri almak için faydalı ipuçları ve bağlantıları sağladığı yargısına katılımcıların 46 'sı \%7.6 ile kesinlikle katıliyorum, 314'ü \%52.2 ile katıllyorum, 149'u \%24.8 ile kararsizım, 75'i \%12.5' i katılmıyorum, 18' i \%3 ile kesinlikle katılmıyorum yantını ile kayıt altına alınmıştır. Katılımcılara tarayıcının bağlantılarını ve geri düğmesini kullanarak sitede dolaşmanın kolay olduğu yargisı verilmiş, katılımcların 41'i \%6.8 ile kesinlikle katıllyorum, 332'si \%55.1 ile katıliyorum, 123'ü \%20.4 ile kararsızım, 82' si \%13.6 ile katılmıyorum, 24'ü \%4 ile kesinlikle katılmıyorum yanıtını vermiştir. Katılımclar web sitesinin güvenilirlik düzeyi yüksektir, bilgilerimi korur yargisına 63'ü \%5 ile kesinlikle katılıyorum, 284'ü \%47.2 ile katılıyorum, 185'i \%30.7 ile kararsızım, 53’ü \%8.8 ile katılmıyorum, 17 'si \%2.8 ile katılmıyorum cevabını vermiştir. EBA web sitesindeyken kullanıcıların çok fazla sayfa açmasına gerek olmayacağına ilişkin yargıya katılımclların 42'si \%7 kesinlikle katıliyorum, 324'ü \%53.8 katıllyorum, 150'si \%24.9 kararsızım, 69'u \%11.5 katılmıyorum, 17'si kesinlikle katılmıyorum demiştir. EBA web sitesinin menüsü standarttır, kolayca anlarım yargısına katılımcılarin 51'i \%8.5 oran ile kesinlikle katilıyorum, 388'i \%64.5oran ile katıliyorum, 87'si \%14.5 ile kararsızım, 55'i \%9.1 oran ile katılmuyorum, 21'i \%3.5 ile kesinlikle katılmıyorum yanıtını vermiştir. Aşağıda EBA web sitesi içinde gezinebilme ve bağlantıları değerlendirme kategorisi ağırlıklı ortalama grafiği yer almaktadır. Katılımclar bu kategoride EBA web sitesinin kullanılabilir olduğuna ilişkin \%8.1 ile kesinlikle katılıyorum, \%55.1 ile katılıyorum, \%22.3 ile kararsızım, \%11.2 ile katılmıyorum, \%3.2 ile kesinlikle katılmıyorum yanıtını verdiği sonucuna ulaşılmıştır. Buna göre velilerin EBA web sitesinde gezinebilme ve bağlantıların kullanılabilirliği kategorisinde orta düzey üstünde kullanılabilir olduğunu belirttiği kayıt altına alınmıştır. 


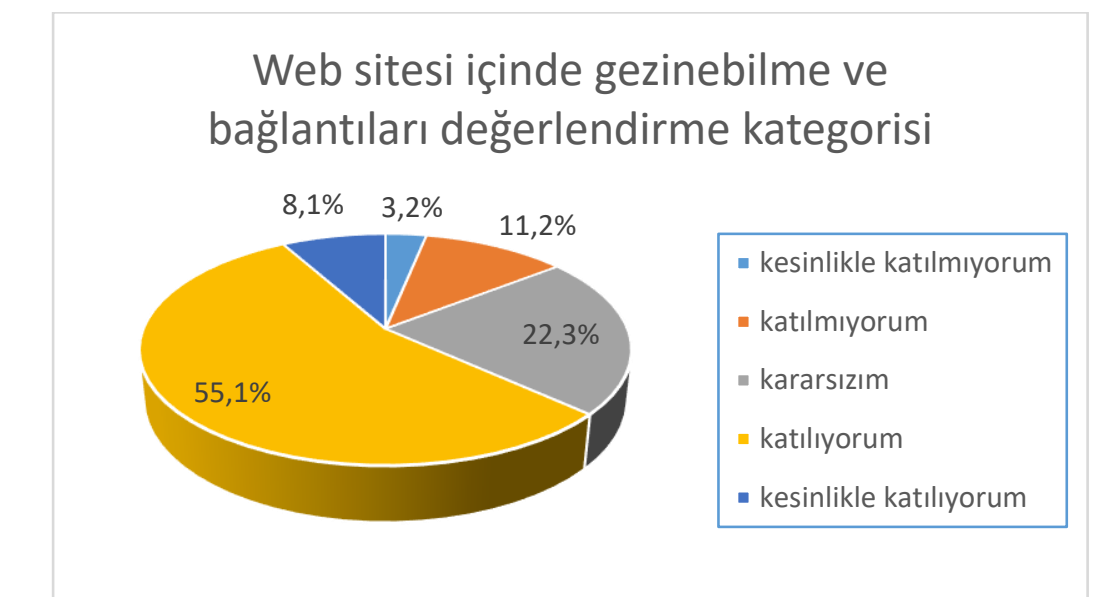

\section{Şekil 7. EBA Web Sitesi İçinde Gezinebilme ve Bağlantılarn Değerlendirme Kategorisi A ̆̆ırlıklı Ortalama Grafiği}

Velilere üçüncü kategoride web sitesinin ara yüzünün kullanılabilirliğine ilişkin 6 yargı verilmiştir. Buna göre EBA web sitesinin tasarımının çekici olduğuna ilişkin yargıya katılımcılar 37 frekans \%6.1 ile kesinlikle katılıyorum, 249 frekans \%41.4 ile katıliyorum, 167 frekans \%27.7 ile kararsızım, 117 frekans \%19.4 oran ile katılmıyorum, 32 frekans \%5.3 ile kesinlikle katılmıorum yanıtını vermiştir. EBA web sitesinde kullanılan renkler konusunda rahat olduklarına ilişkin yargıya ise 43 frekans \%7.1 oran ile kesinlikle katılıyorum, 386 frekans \%64.1 ile katilıyorum, 114 frekans \%18.9 ile kararsızım, 42 frekans $\% 7$ oran ile katılmıyorum, 17 frekans $\% 2.8$ oran ile kesinlikle katılmıyorum yanıtını vermiştir. Web sitesinde döngülü animasyonların ve yanıp sönen metinlerin rahatsız etmediğine ilişkin yargıya katılımcıların 60' $1 \% 10$ ile kesinlikle katıliyorum, 395'i \%65.6 oran ile katıliyorum, 89'u \%14.8 ile kararsizım, 39'u \%6.6 ile katılmıyorum, 19'u \%3.2'si kesinlikle katılmıyorum cevabı ile kayıt altına alınmıştır. EBA web sitesinin tutalı bir his ve görünüme sahip olduğuna ilişkin yargıya katılımclların 41'i \%6.8 ile kesinlikle katılıyorum, 363'ü \%60.3'ü katiliyorum, 124'ü \%20.6 oran ile kararsızım, 52'si \%8.6'sı katılmıyorum 22'si kesinlikle katılmıyorum yanıtını vermiştir. EBA web sitesinin fazla reklam içermediğine ilişkin yargıya katılımcıların 91'i \% 15.1 'i kesinlikle katılıyorum, 389'u \%64.6 ile katılıyorum, 65'i \%10.8 ile kararsızım, 38'i \%6.3 ile katılmıyorum, 19'u \%3.2 ile kesinlikle katılmıyorum yanıtını verdiği kayıt altına alınmıştır. EBA web sitesinin tasarımın anlamlı olduğu ve nasıl 
kullanılacağının öğrenilmesinin kolay olduğuna ilişkin yargıya katılımcıların 68'i \%11.3 ile kesinlikle katılıyorum, 376's $\% 62.5$ ile katilıyorum, 97'si \%16.1 ile karasızım, 45'i \%7.5 ile katılmıyorum, 16's1 \%2.7 oran ile kesinlikle katılmiyorum yanıtını verdiği kaydedilmiştir. Aşağıda EBA web sitesinin ara yüzünün kullanılabilirliğine ilişkin verilen yanıtların ağırlıklandırılmış ortalamalarını gösteren pasta grafik bulunmaktadır. Katılımcıların web sitesinin ara yüzünün kullanılabilir olduğuna ilişkin yargıları \%9.4 oranında kesinlikle katıliyorum, \%59.7 katılıyorum, \%18.2 kararsızım, \%9.2 katılmıyorum, \%3.5 kesinlikle katılmıyorum yanıtını vermiştir. Bu verilere göre EBA web sitesinin ara yüzünün kullanılabilirliğine ilişkin veliler orta düzeyin üstünde yargı belirtmişlerdir.

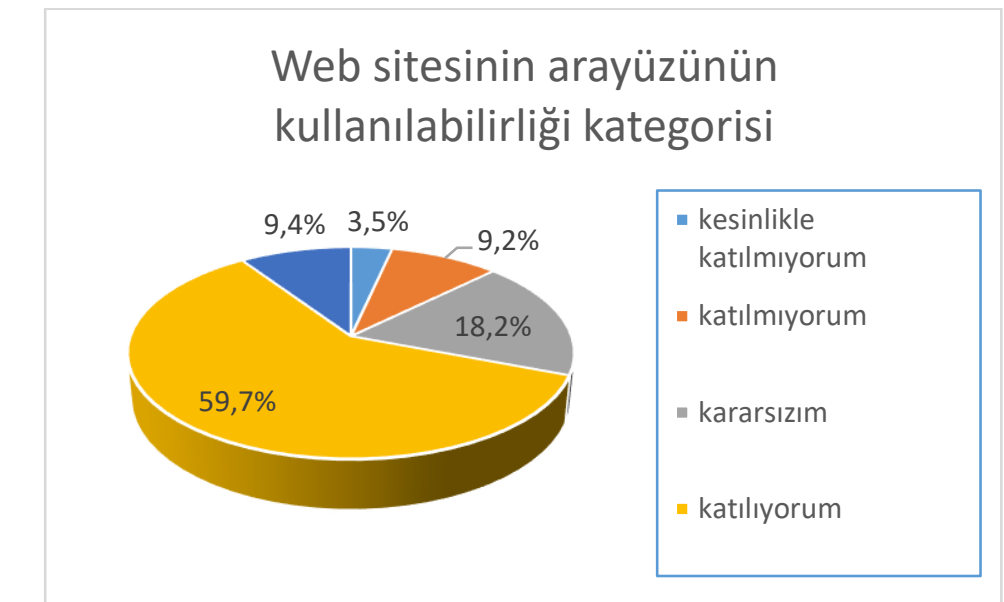

\section{Şekil 8. EBA Web Sitesinin Ara Yüzünün Kullanılabilirliği Kategorisi Ağırlkkl Ortalama Grafiği}

Araştırmanın dördüncü kategorisinde sayfanın performansı ve etkililiğine ilişkin değerlendirme yargıları verilmiştir. Katılımclar EBA web sitesinde ziyaret ettikleri ve etmedikleri bağlantıları kolayca ayırt edebildiklerine ilişkin yargıya 35 frekans \%5.8 ile kesinlikle katılıyorum, 292 frekans ile \%48.5 oran ile katılıyorum, 177 frekans \%29.4 oran ile kararsızım, 77 frekans \%12.8 ile katılmıyorum ve 21 frekans \%3.5 oranla kesinlikle katılmıyorum yanıtını vermiştir. EBA web sitesine çoğu zaman erişebiliyorum yargısına katılımc1ların 41 frekans ile \%6.8'i kesinlikle katılıyorum, 316's \%52.5 ile katıliyorum, 96 frekans ile \%15.9'u kararsızım, 104 frekans ile \%17.3'ü katılmıorum, 45 
frekans ile \%7.5'i kesinlikle katılmıyorum cevabını verdiği kayıt altına alınmıştır. EBA web sitesinin velilerin eylemlerine beklendiği gibi, yanıt verdiğine ilişkin yargıya katılımcıların 31 frekans ile \%5.1'i kesinlikle katılmıyorum, 289 frekans ile \%48'i katılıyorum, 152 frekans ile \%25.2'si kararsızım, 103 frekans ile \%17.1'i katılmıorum ve 27 frekans ile \%4.5'i kesinlikle katılmıyorum yanıtını vermiştir. EBA web sitesini kullanmanın etkili olduğuna ilişkin yargiya katılımciların 45 frekans ile \%7.5'i kesinlikle katıllyorum, 336's \%55.8'i katılıyorum, 129 frekans ile \%21.4'ü kararsızım, 69 frekans ile \%11.5' $\mathrm{i}$ katılmıyorum, 23'ü \%3.8'i kesinlikle katılmıyorum demiştir. EBA web sitesinin içinde nasıl ilerleyeceğini bilmediğinde her zaman açık ve faydalı mesajlar verir yargısına katılımciların 47 frekans ile \%7.8 kesinlikle katılıyorum, 278 frekans ile \%46.2 oranla katılıyorum, 167 frekans ile \%27.7 oran ile kararsızım, 70 frekans ile $\% 13.1$ katıllyorum, 31 frekans ile $\% 5.1$ oranla kesinlikle katılmuyorum yanıtı kayıt altına alınmıştır. Aşağıda EBA web sitesinin performansı ve etkililiğine ilişkin verdikleri yanıtların ağırlıklandırılmış ortalamalarını gösteren pasta grafik bulunmaktadır. EBA web sitesinin performansı ve etkililiğine ilişkin velilere göre katılımcıların \%6.7 si kesinlikle katılıyorum, \%48.5'inin katıllyorum, \%24'ünün kararsızım, \%15.6'sının katılmıyorum, \%5.2'sinin kesinlikle katılmıyorum yanıtını vermiştir. Bu verilere göre EBA web sitesinin kullanan velilerin web sitesinin performansı ve etkililiğine ilişkin orta düzey üstünde kullanılabilir olarak değerlendirdiği söylenebilir.

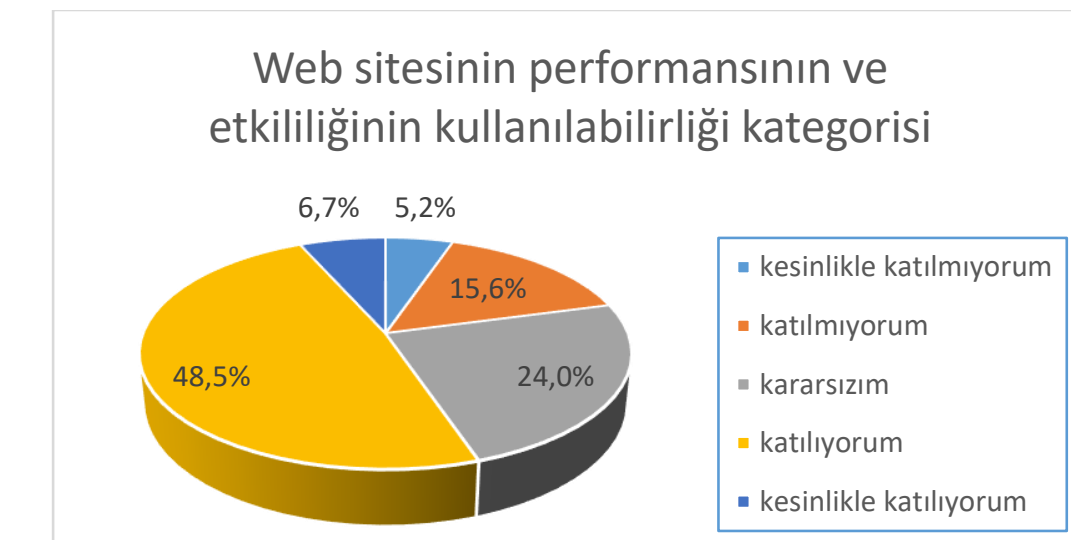

Şekil 9. EBA Web Sitesinin Performansının ve Etkililiğinin Kullanılabilirliği Kategorisi Ağırlıklı Ortalama Grafiği 


\section{Sonuç ve Tartışma}

Teknolojik gelişmelerin 2000'li yıllarla insan yaşamina hizlı entegrasyonu devletleri de aynı ölçüde e hizmetler çerçevesinde itici bir güçle yenilenmeye yönelttiği bilinmektedir. Devletler sundukları hizmetleri vatandaşın fiziksel yakınlık arz etmeden gerçekleştirebileceği güvenli, hızlı ve mekânsız bir anlayışla ele almakta ve her alanda e-hizmet üretmek için yatırımlar gerçekleştirmektedir. Çeşitli alanlarda üretilen bu hizmetler özellikle pandemi ile insan sağlığı ve insanlar arasındaki mesafelerin önemli olduğu bir dönemde daha da öne çıkmış bu noktada ulaştığı hedef kitle açısından hızla artan bir ivme göstermiştir. Eğitim bu alanlardan sadece biridir. Ve dünya ülkelerinde olduğu gibi Türkiye'de de var olan yatırımlar ile geliştirilen EBA platformu uzaktan eğitim sürecinin resmi olarak tüm ülkede uygulanmaya başladığı andan itibaren kullanıcı rakamlarını katlamıştır. Bu noktada öğrenci, öğretmen ve veli üçgeninde her hedef kitle için ayrı nitelikleriyle değerlendirilen EBA bir e-hizmet olarak çalışmalara konu olmuştur. Bu çalışmada özellikle evden eğitim süreci içerisinde daha fazla rol üstelenen velilerin EBA platformuna ilişkin kullanılabilirlik alanında görüşleri araştırılmış ve sonuçlar değerlendirilmiştir.

Araştırmanın çevrimiçi anket uygulaması yöntemiyle gerçekleşmiş olması göz önüne alınarak gönüllü katılımcıların özellikle kadınlar olması dikkat çekici bir sonuçtur. Ankete katılımın sağlanması amacıyla Whatsapp grupları üzerinden yayılımın sağlanmasının sonucu olarak veli sınıf gruplarında paylaşılması bu nedenle kadınların daha yüksek oranda katılım sağladığı öngörüsünü ortaya koyabilir diğer yandan bu konu da ayrı bir çalışma konusu olarak değerlendirilebilir. Araştırmaya katılan katılımcıların çocuklarının öncelikli olarak cep telefonların kullanarak EBA'ya bağlandığı ve yine bu öğrencilerin öncelikli olarak ilkokul seviyesinde eğitim aldığı söylenebilir. EBA web sitesinin içeriği, düzeni ve okunabilirliği kategorisinde "kullanılabilir" olduğuna ilişkin katılımcıların \%8.4 oranında kesinlikle katılıyorum, \%:51.5 oraninda katilıyorum, \%21.2 oranında kararsızım, \%14.3 oranında katılmıyorum, \%4.5 oranında kesinlikle katılmıyorum yanıtını verdiği sonucuna ulaşılmıştır. Bu verilere göre EBA web sitesinin veliler tarafından sitenin içeriği, düzeni ve okunabilirliği kategorisinde orta düzeyin üstünde kullanılabilir olduğunuza ilişkin fikir beyan ettiği söylenebilir. Katılımcılar web sitesi içinde gezinebilme ve bağlantıları değerlendirme kategorisinde 
EBA web sitesinin kullanılabilir olduğuna ilişkin \%8.1 ile kesinlikle katılıyorum, \%55.1 ile katilıyorum, \%22.3 ile kararsızım, \%11.2 ile katılmıyorum, \%3.2 ile kesinlikle katılmıyorum yanıtını verdiği sonucuna ulaşılmıştır. Buna göre velilerin EBA web sitesinde gezinebilme ve bağlantıların kullanılabilirliği kategorisinde orta düzey üstünde kullanılabilir olduğunu belirttiği kayıt altına alınmıştır. Katılımcların web sitesinin ara yüzünün kullanılabilir olduğuna ilişkin yargıları \%9.4 oranında kesinlikle katılıyorum, \%59.7 katılıyorum, \%18.2 kararsızım, \%9.2 katılmıyorum, \%3.5 kesinlikle katılmıyorum yanıtını vermiştir. Bu verilere göre EBA web sitesinin ara yüzünün kullanılabilirliğine ilişkin veliler orta düzeyin üstünde yargı belirtmişlerdir. EBA web sitesinin performansı ve etkililiğine ilişkin velilere göre katılımcıların $\% 6.7 \mathrm{si}$ kesinlikle katıliyorum, \%48.5'inin katılıyorum, \%24'ünün kararsızım, \%15.6'sinın katılmıorum, \%5.2'sinin kesinlikle katılmıyorum yanıtını vermiştir. Bu verilere göre EBA web sitesinin kullanan velilerin web sitesinin performansı ve etkililiğine ilişkin orta düzey üstünde kullanılabilir olarak değerlendirdiği söylenebilir.

E-anket yöntemi ile web sitesi kullanılabilirliği anketi ile dört ayrı kategoride değerlendirilen sonuçlar ile velilerin orta düzeyin üstünde EBA web sitesinin kullanılabilir olduğu görüşüne sahip olduğu ortaya konmuştur. Bu noktadan hareketle bugün Türkiye'de devlet okullarında pandemi sürecinde EBA platformundan eğitim alan öğrencilerin velileri sitenin kullanılabilirlik düzeyi açısından değerlendirildiğinde kullanılabilir olarak değerlendirildiği kayıt altına alınmıştır. Diğer yandan bir tartışma alanı olarak araştırmanın sınırlılığı olarak değerlendirilen husus; anketin ulaştırıldığı bazı noktalardan internetin sağlıklı olarak ulaşlamadığı köylerde öğrencilerin EBA web sitesine bağlanamadıkları geri dönütünün alınması olmuştur. Bu noktada web sitesinin kullanılabilirliğinin değerlendirildiği bu araştırma EBA öğretim sisteminin yayginlığı ile ilişkili değildir.

Kamu hizmetinin bilgi ve teknoloji çağının en etkin yaşandığı günümüzde, hizmetin verildiği web sitelerinin "kullanılabilirliği" önemli bir gündemi oluşturmaktadır. Devletin özellikle pandemi döneminde kamuya sağladığı hizmetlerin ön sıralarında gelen dijital eğitim platformu olarak EBA platformunun veliler nezdinde ne ölçüde kullanılabilir olduğunu ortaya koymak da aynı önemi işaret etmektedir. Geleneksel eğitimin işlevselliğini arttırmak amacıyla uzaktan eğitim yöntemleri Türkiye' de pandemi öncesinde ha- 
yata geçirilmiştir. Pandemi döneminde evdeki öğretmenlere dönüşmeye başlayan veliler için EBA web sitesinin kendi açllarından kullanılabilirliğinin ortaya konması bu noktada önemli görülerek değerlendirilmiş ve araştırmaya katılan veliler tarafından EBA web sitesinin kullanılabilirliğinin orta düzey üstünde olduğu sonucuna ulaşılmıştır 


\title{
EXTENDED ABSTRACT
}

\section{Usability of Websites as a Public Service Tool: EBA Example}

\author{
$*$ \\ Hicran Özlem Ilgın - Şaziye Ceren Ulupınar \\ Çanakkale Onsekiz Mart University- Çanakkale Onsekiz Mart University
}

Today, being able to do most of the work to be done online can prevent loss of time for individuals and provides relative advantages. Today, the internet, which has become a means of providing the services of states, is a concept that positively structures the concepts of transparent, democratic, participatory and accountability when we look at it from the perspective of administration. In this context, when the interactive environment of the internet, which does not know the time and place limits, is used effectively in terms of communication, it turns into an advantage in the production of government services. Education from the public services of the state has brought about change along with technology. Efforts are being made to integrate information and communication technologies into education today. In Turkey, by the General Directorate of Innovation and Educational Technologies, Education Informatics Network (EBA) has been created free of charge for the use of teachers, students and parents. With this system, teachers, students and parents have the opportunity to access resources such as video narration as well as text, sound and picture features with educational contents. The provision of educational and training resources in electronic environment contributes to students' access to information and supports their learning processes. In addition, EBA offers the opportunity to reach the performance information of the student by the parents. This reveals the interactive environment of EBA with students, teachers and parents, and from this point on, it turns parents into a target mass. Especially during the pandemic period, face-to-face education cannot continue in schools and in an education period that is carried out digitally from home, the EBA website appears as an important educational environment as a public service in the triangle of parents, teachers and students. 
Based on these points, this study focuses on the evaluation of the EBA website, which is an electronic learning environment that made its importance felt during the pandemic period, as a government e-service by parents. In the literature section of the study, the web sites as a public service tool and their examples and the literature on the EBA environment have been evaluated. With the emergence of the Coronavirus pandemic in 2019, distance education platforms have also become an important learning resource. The impact of the pandemic on education around the world has also highlighted different needs and approaches. The pandemic showed that the learning process should be continued without interruption, there is a greater need for distance education and investment should be made in this field, and alternative learning approaches should be given more importance than necessary.

The subject of this research is the thoughts of parents whose children use the web face of the EBA system during the Covid 19 pandemic about the usability of the website. The aim of the study is to reveal to what extent the EBA distance education platform, which is evaluated during the distance education period, can be used by parents. Based on the fact that the studies on EBA are teachers and students, it is thought that a research with parents will be important in the literature.

In the method of the study, the 24-question scale developed by Chiew and Salim (2003, p.47-57) and included in the "Webuse: Website Usability Evaluation Tool" study was used with the online survey method. The scale to be used in the questionnaire can be unanimously evaluated by the decision of the Scientific Research Ethics Committee of Çanakkale Onsekiz Mart University Graduate Education Institute, dated 04/01/2021 and numbered 01/24, that it complies with the principles of the Scientific Research Ethics Committee. has been taken. Questions asked in the research; The content, layout and readability of the website were evaluated under 6 questions and 4 main categories: 6 questions to navigate the website and evaluate the links, 6 questions to evaluate the interface of the website, and to evaluate the performance and effectiveness of the page. In the questionnaire, in order to make demographic evaluations, the gender, age, occupation, city of residence, educational status of the child, education level of the child and the device they provide access to EBA were also asked in the questionnaire. The survey was conducted online as it was conducted during the pandemic period. Before the questionnaire was initiated for pre-evaluation purposes, it was applied to 20 participants on 
a digital platform, its reliability results were evaluated, and the questionnaire prepared on Google Docs between 06-07 January 2021 was presented to open participation on social media platforms. Reaching the 384 number determined for the survey sample was determined as the main condition for the survey implementation period, during this period, online participation was made. Within this specified period, the number of participants was reached beyond the planned number.

With the e-survey method and the results evaluated in four different categories with the web site usability questionnaire, it was revealed that the parents had the opinion that the EBA web site could be used above the middle level. From this point of view, it has been recorded that the parents of the students who receive education from the EBA platform during the pandemic process in public schools in Turkey are considered usable when evaluated in terms of the usability level of the site. On the other hand, the issue considered as the limitation of the research as a discussion area; In villages where internet is not accessible from some points where the questionnaire was delivered, the feedbacks of the students who could not connect to the EBA website were received. At this point, this study, in which the usability of the website is evaluated, is not related to the prevalence of the EBA teaching system.

\section{Kaynakça / References}

Akyürek, M. İ.. (2020). Uzaktan eğitim bir alanyazın taraması. Medeniyet Eğitim Araşturmalarn Dergisi,1, 1-9.

Bal, H. ve Boz, M. S.(2017). Ĕğitim bilişim ağı (eba) kullanılabilirlik düzeyinin ölçülmesi. Ankara, Milli Eğitim Bakanlı̆̆ Yayınları.

Bertot, J. ve Jaeger, P. (2008). The e-government paradox: better customer service doesn't necessarily cost less. Government Information Quarterly, 25(2), 149-154.

Can, E. (2020). Coronavirüs (Covid-19) pandemisi ve pedagojik yansımaları: Türkiye'de açık ve uzaktan eğitim uygulamaları, Açıöğretim Uygulamaları ve Araştırmaları Dergisi, 6(2), 11-53.

Chiew, T. K. ve Salim, S. S. (2003). Webuse: Website usability evaluation tool, Malaysian Journal of Computer Science, 16(1), 47-57.

Çakmak, Z. ve Taşkıran, C. (2017). Sosyal bilgiler öğretmenlerinin perspektifinden eğitim bilişim ağı (EBA) platformu. Uluslararası Türk Eğitim Bilimleri Dergisi, 9, 284-295.

Çukurçayir, M. A. ve Eşki, H. (2001). Kamu hizmeti sunumunda yeni yöntemler. S. Ü. İ̈BF Sosyal ve Ekonomik Araştırmalar Dergisi, 1, 89-109. 
Demir, D., Özdinç, F. ve Ünal, E. (2018). Eğitim bilişim ağı(eba) portalına katılımın incelenmesi. Erzincan Üniversitesi Ĕ̆itim Fakültesi Dergisi, 2, 407-422.

Durmuş, S. ve Çağıltay, K. (2012). Kamu kurumu web siteleri ve kullamlabilirlik, (Ed.), M. Z. Sobacı ve M. Yıldız. E-devlet kamu yönetimi ve teknoloji ilişkisinde güncel gelişmeler, içinde (s.293-322). İstanbul: Nobel Yayıncllk.

Dündar, E. ve Karaağaçlı, M. (2019). Öğretmenlerin EBA (Eğitim Bilişim Ağı) İle İlgili Algilarının Eğretilemeler Aracllı̆ıyla Belirlenmesi. Social and Human Scientific, 6, 247-259.

Erkul, E. (2009). Sosyal medya araçlarının (web 2.0) kamu hizmetleri ve uygulamalarında kullanılabilirliği. Türkiye Bilişim Derneği, 116, 96-101.

Grunig, J. E. ve Grunig, L. A. (2005). Halkla ilişkiler ve iletişim modelleri, halkla ilişkiler ve iletişim yönetiminde mükemmellik, (Çev: E. Özsayar). İstanbul: Rota Yayınları.

Kaçan, A. ve Gelen, İ. (2020). Türkiye'deki uzaktan eğitim programlarına bir bakış. Uluslararası Ĕgitim Bilim ve Teknoloji Dergisi, 6, 1-21

Karaçorlu, A. T. ve Atıcı, B. (2019). EBA platformundaki kavram haritaları ve infografiklerin kullanımına dair öğretmen ve öğrenci görüşleri. Gazi Eğitim Bilimleri Dergisi, 5, 83-105.

Kazancı, M. (1997). Halkla ilişkiler. Ankara: Turhan Kitabevi.

Kocabulut, Ö. ve Albayrak, T. (2017). Web sitesi hizmet kalitesinin müşteri memnuniyetine etkileri. Anatolia: Turizm Araştırmalarn Dergisi, 28(2), 293-303.

Kutup, N. (2010). İnternet ve Sanat, Yeni Medya ve net.art. Akademik Bilişim'10- XII. Akademik Bilişim Konferansı, 10-12 Şubat, Muğla Üniversitesi, 9-20.

Öner, G. (2017). Sosyal bilgiler ve tarih dersleri için alternatif bir kaynak: EBA.gov.tr. Uluslararası Türk Eğitim Bilimleri Dergisi, 9, 227-257.

Türk Bilişim Derneği (TBD), (2006). e-Devlet Kavramları El Kitabı. VIII, Ankara, Kamu Bilişim Platformu.

West, D. M. (2004). E-government and the transformation of service delivery and citizen attitudes. Public Administration Review, 64 (1), 15-27.

Yılmaz, E., Güner, B., Mutlu, H., Doğanay, G., Yılmaz, D. (2020). Veli algisına göre pandemi dönemi uzaktan eğitim sürecinin niteliği. Konya: Palet Yayınları, 25.12.2020 tarihinde http://paletyayinlari.com.tr/wp-content/uploads/2020/Uzaktan_egitim_surecinin_niteligi.pdf. adresinden erişildi.

T.C. Milli Eğitim Bakanlığı (2020). Nasll TV. 17.12.2020. tarihinde http://www.eba.gov.tr/nasil-tv.html. adresinden erişildi.

T.C. Cumhurbaşkanlığı Strateji ve Bütçe Başkanlığı Bilgi ve İletişim Teknolojileri Dairesi (2020)., Bilgi toplumu 10.12.2020. tarihinde http://www.bilgitoplumu.gov.tr/timeline/. adresinden erişildi. 
Similar Web (2020). Similar web. 17.12.2020 tarihinde https://www.similarweb.com/website/EBA.gov.tr/\#overview. Adresinden erişildi

Google (2020). $\quad$ Google. $20.12 .2020 \quad$ tarihinde https://trends.google.com.tr/trends/yis/2020/TR/adresinden erişildi.

T.C. Milli Eğitim Bakanlığı (2020). Eba eğitim platformu Dünyada birinci straya yerleştir. 19.12.2020 tarihinde http://yegitek.meb.gov.tr/www/eba-egitim-platformudunyada-1-siraya-yerlesti/icerik/3092 adresinden erişildi.

\section{Kaynakça Bilgisi / Citation Information}

Ilgın, H. Ö., Ulupınar, C. (2021). Kamu hizmet aracı olarak web sitelerinin kullanılabilirliği: EBA örneği. OPUS-Uluslararası Toplum Araştırmaları Dergisi, 17(37), 4154 - 4180. DOI: 10.26466/opus.860386 